\title{
Dimensi Ekonomi Produktif dalam Regulasi Wakaf di Indonesia
}

\author{
Solikhul Hadi \\ Institut Agama Islam Negeri Kudus \\ Solikhul623@gmail.com
}

\begin{abstract}
Waqf is a form of worship in Islam which has productive economic value. And Law no. 41 of 2004 concerning Waqf has opportunities for economic development for the benefit of social welfare. For this reason, it is necessary to have a study that analyzes the Waqf Law from a productive economy perspective. In this study, using content analysis method, which is an in-depth discussion of the content of written or printed information. In this case Law No.41 of 2014 concerning Waqf seeks to be coherent with productive economic theory. And the theory used as an analysis tool is the productive economic theory of Qutub Abdul Salam, in terms of the dimensions of productive economic goals and the main factors needed. Thus, this research actually aims to find the coherence of the articles in the Waqf Law with the Productive Economic Theory developed by Qutub Abdul Salam. From the results of data collection and analysis, it can be concluded that the Waqf Law is kohern with productive economic theory. The purpose of productive economic activities is to increase the benefit that can be realized in various forms, including: Meeting human needs at a moderate level, finding community needs and their fulfillment, providing supplies of goods / services in the future and fulfilling the means for social activities and worship of Allah. Among the articles in the Waqf Law which are coherent with productive economic objectives is article 5 of the Waqf Law, which explains that waqf functions to realize the economic potential and benefits of waqf assets for the benefit of worship and to promote public welfare. In productive economic theory, the productivity factors of a business include four things: natural resources, managers / workers, skills and capital. The natural resource factor as one of the factors in the development of the productive economy is coherent with the Waqf Law, namely waqf objects in the form of land, buildings or other immovable objects. The productivity factor in the form of managers or workers managing and carrying out waqf assets is nazir which includes; individual, organization, or legal entity. Skill is a very important productivity factor in managing waqf assets. Nazir as the manager of the waqf will receive guidance from the Minister of Religion and the Indonesian Waqf Board (BWI) both in terms of skills and managerial. And the capital factor in the context of the management of waqf assets is the object of waqf. In the Law on Waqf the objects of waqf include movable and immovable objects. With the issuance of the Waqf Law No. 41 of 2014, immovable objects have become important assets in the development of productive waqf. Movable property that cannot be used up due to consumption includes: money, precious metals, securities, vehicles, intellectual property rights, lease rights and other movable objects in accordance with the provisions of sharia and applicable laws and regulations.
\end{abstract}

Keywords: Productive Economy, Indonesian Waqf Regulation. 


\begin{abstract}
Abstrak
Wakaf adalah suatu ibadah dalam agama Islam yang mempunyai nilai ekonomi produktif. Dan UU No. 41 Tahun 2004 tentang Wakaf memiliki peluang untuk pengembangan ekonomi guna kemaslahatan kesejahteraan sosial. Untuk itu perlu adanya studi yang menganalisis UU Wakaf dalam perspektif Ekonomi produktif. Dalam penelitian ini menggunakan metode analisis isi (content analysis) yaitu analisis yang bersifat pembahasan mendalam terhadap isi suatu informasi tertulis atau tercetak. Dalam hal ini UU No.41 Tahun 2014 tentang Wakaf berusaha untuk dikoherensikan dengan teori ekonomi produktif. Dan teori yang digunakan sebagai pisau analisis adalah teori ekonomi produktif dari Qutub Abdul Salam, dalam dimensi tujuan ekonomi produktif dan faktor-faktor utama yang dibutuhkan. Dengan demikian, penelitian ini sesungguhnya bertujuan untuk menemukan koherensi pasal-pasal dalam UU Wakaf dengan Teori Ekonomi Produktif yang dikembangkan oleh Qutub Abdul Salam. Dari hasil pengumpulan data dan analisis maka dapat disimpulkan bahwa UU Wakaf kohern dengan teori ekonomi produktif. Tujuan kegiatan ekonomi produktif adalah meningkatkan kemaslahatan yang bisa diwujudkan dalam berbagai bentuk di antaranya: Pemenuhan kebutuhan manusia pada tingkat moderat, menemukan kebutuhan masyarakat dan pemenuhannya, menyediakan persediaan barang/ jasa di masa depan dan pemenuhan sarana bagi kegiatan sosial dan ibadah kepada Allah. Diantara pasal dalam UU Wakaf yg kohern dengan tujuan ekonomi produktif adalah pasal 5 UU Wakaf, yang menjelaskan bahwa wakaf berfungsi mewujudkan potensi dan manfaat ekonomis harta benda wakaf untuk kepentingan ibadah dan untuk memajukan kesejahteraan umum. Dalam teori ekonomi produktif faktor- faktor produktifitas suatu usaha mencakup empat hal: sumber daya alam, pengelola/pekerja, skill dan modal. Faktor sumber daya alam sebagai salah satu faktor dalam pengembangan ekonomi produktif kohern dengan UU Wakaf yaitu obyek wakaf dalam bentuk tanah, bangunan atau benda tidak bergerak lainnya. Faktor produktifitas dalam bentuk pengelola atau pekerja yang mengurus dan menjalankan harta benda wakaf adalah nazir yang meliputi; perseorangan, organisasi, atau badan hukum. Skill merupakan faktor produktifitas yang sangat penting dalam mengelola harta benda wakaf. Nazir selaku pengelola wakaf akan mendapatkan pembinaan dari Menteri Agama dan Badan Wakaf Indonesia (BWI) baik dari aspek skill maupun managerial. Dan Faktor modal dalam konteks pengelolaan harta wakaf adalah obyek wakaf. Dalam UU Wakaf obyek wakaf meliputi benda bergerak dan tidak bergerak. Dengan keluarnya UU Wakaf No 41 Tahun 2014 maka benda tidak bergerak menjadi modal penting dalam pengembangan wakaf produktif. Harta benda bergerak yang tidak bisa habis karena dikonsumsi meliputi: uang, logam mulia, surat berharga, kendaraan, hak atas kekayaan intelektual, hak sewa dan benda bergerak lain sesuai dengan ketentuan syariah dan peraturan perundang-undangan yang berlaku.
\end{abstract}

Kata Kunci: Ekonomi Produktif, Regulasi Wakaf Indonesia. 


\section{PENDAHULUAN}

Wakaf memiliki dimensi keagamaan, kebudayaan serta sosial ekonomi (Ali Sabri, F, 2013: 41). Regulasi wakaf sebagai sarana pengembangan ekonomi produktif terjadi di beberapa negara muslim. Negara-negara muslim yang telah mengembangkan regulasi hukum wakaf dalam ranah ekonomi produktif antara lain; Arab Saudi, dan Bangladesh (Djunaidi, 2007: 32-42). Namun sayangnya di Indonesia sejak lama sekali wakaf belum bisa mengangkat nilai sosial ekonomi. Faktanya wakaf lebih diimplementasikan pada ranah konsumtif, belum produktif (Khusaeri, 2015: 78).

Salah satu faktor penting yang ikut mewarnai corak dan perkembangan wakaf di Indonesia adalah ketika negara ikut mengatur kebijakan wakaf melalui seperangkat hukum positif. Dalam proses perumusan kebijakan tersebut, visi dan arah kebijakan wakaf banyak ditentukan oleh bagaimana rezim berkuasa melihat potensi maupun organisasi wakaf, baik dalam kerangka kepentingannya maupun kepentingan umat Islam pada umumnya (Najib, 2006: 81).

Di masa penjajahan, politik pemerintah mengenai filantropi Islam tunduk pada rasionalitas politik Islam Hindia Belanda, di mana Islam sebagai sistem nilai yang kaya akan dimensi sosial dengan berbagai preseden sejarah politiknya, dibatasi sedemikian rupa sehingga ia dipraktikkan dalam kerangka ritual-personal semata (Suminto, 1985: 120). Mengingat aktivitas filantropi Islam seringkali berhubungan antar anggota-anggota masyarakat, maka pemerintah kolonial pada akhirnya memandang perlu untuk mengatur perwakafan dengan regulasi. Sayangnya kebijakan yang dibuat tidak sepenuhnya didasarkan pada keinginan politik (political will) yang jujur serta pemahaman yang benar tentang hakikat dan tujuan filantropi Islam; akibatnya ia tidak memiliki arti penting bagi pengembangan wakaf, selain memenuhi formal administratif wakaf belaka (Najib, 2006: 82).

Regulasi hukum wakaf pada masa kolonial mulai ditetapkan pada tahun 1905. Regulasi hukum wakaf yang pertama dikeluarkan oleh pemerintah Hindia Belanda pada tahun 1905 adalah Surat Edaran Sekretaris Governemen tanggal 31 Juni tahun 1905 dan termuat di dalam Bijblad 1905 Nomor 6196. Selanjutnya, pemerintah Hindia Belanda mengganti regulasi wakaf tahun 1905 tersebut dengan Surat Edaran Sekretaris Governemen tahun 1931, 1934 dan 1935. Peraturan-peraturan tersebut pada intinya mengatur tentang wakaf tanah, pembangunan masjid dan perizinannya (Praja, 1997: 33).

Setelah kemerdekaan regulasi hukum wakaf di Indonesia mengalami perkembangan cukup penting, yang dapat digambarkan dalam beberapa fase sebagaimana berikut: 
Pertama, fase Orde Lama, regulasi hukum wakaf diatur di dalam UU No. 5 Tahun 1960 tentang Peraturan Dasar Pokok-Pokok Agraria di mana negara secara resmi menyatakan perlindungan terhadap harta wakaf. Dalam Pasal 49 ayat (3) dikatakan bahwa perwakafan tanah milik dilindungi dan diatur menurut peraturan pemerintah (Hasanah, 2008: 13).

Kedua, fase Orde Baru, regulasi hukum wakaf diatur dengan Peraturan Pemerintah No. 28 Tahun 1977 tentang Perwakafan Tanah Milik. Regulasi ini tergolong sebagai peraturan yang pertama yang memuat unsur-unsur substansi dan teknis perwakafan. Peraturan Pemerintah ini mengatur perwakafan tanah milik, yang meliputi inventarisasi tanah wakaf, proses terjadinya perwakafan tanah milik, dan proses pemberian hak atas tanah wakaf. Peraturan ini terbit setelah 17 tahun diterbitkannya UU No. 5 Tahun 1960 tentang Peraturan Dasar Pokok-Pokok Agraria. Pada fase ini juga diterbitkan Instruksi Presiden No. 1 Tahun 1991 tentang Kompilasi Hukum Islam (KHI), yakni pada Buku III tentang Perwakafan. Aturan ini membawa beberapa pembaharuan dalam pengelolaan wakaf. Pembaharuan ini pada dasarnya merupakan elaborasi dari prinsip pembaharuan yang terdapat pada Peraturan Pemerintah No. 28 Tahun 1977 tentang Perwakafan Tanah Milik. Baik PP No. 28 Tahun 1977 maupun Inpres No. 1 Tahun 1991 diarahkan untuk unifikasi mazhab dan hukum Islam di Indonesia (Azhary, 2004).

Peraturan lainnya yang berkaitan dengan hukum wakaf adalah Undang-Undang Republik Indonesia No. 7 Tahun 1989 tentang Peradilan Agama. Undang-Undang tersebut di dalam Bab III tentang Kekuasaan Pengadilan, Pasal 49 ayat (1) menyebutkan bahwa Pengadilan Agama bertugas dan berwenang memeriksa, memutus, dan menyelesaikan perkara-perkara di tingkat pertama antara orang-orang yang beragama Islam di bidang; a. Perkawinan; b. Kewarisan, wasiat, dan hibah, yang dilakukan berdasarkan hukum Islam; c. Wakaf dan sedekah (Hasanah, 2008: 20).

Pada Era Reformasi barulah muncul regulasi wakaf yang diharapkan mengangkat nilai sosial ekonomi dalam wakaf yaitu UU No. 41 Tahun 2004 tentang Wakaf. Dalam tinjauan ekonomi, UU No. 41 Tahun 2004 tentang Wakaf bertujuan untuk pemberdayaan wakaf secara produktif guna kemaslahatan kesejahteraan sosial.

\section{KAJIAN LITERATUR}

Peneliti telah melakukan telaah terhadap jurnal-jurnal yang relevan dengan penelitian ini. Ali Sabri membahas Wakaf uang sebagai alternatif dalam mensejahterakan ummat ( 2013). Hari Candra lebih melihat pada peran lembaga pendidikan wakaf dalam membentuk karakter bertoleransi (2017). Ahmad Furqon mengupas tentang wakaf sebagai 
solusi permasalahan-permasalahan dunia pendidikan di Indonesia( 2012). Choirul Hadi menelaah Peluang Wakaf Produktif untuk Pembiayaan Pendidikan Islam(2009). Spiritualitas Islam dalam kewirausahaan ditulis oleh Hanifiyah (2016). Uswatun Hasanah menulis Wakaf dalam Peraturan Perundang-undangan di Indonesia (2008). Hasbullah Hilmi menulis tentang Dinamika Pengelolaan Uang Wakaf (Studi tentang Perilaku Pengelolaan Wakaf Uang Pasca Pemberlakuan UU No. 41 Tahun 2004) (2012). Khusaeri menulis tentang Wakaf Produktif (2015). Abdul Haris Naim memaparkan tentang Pengembangan Obyek Wakaf dalam Fiqh Islam dan Hukum Positif di Indonesia (2017). Diyah Ayu Zahrotul Jannah menulis tentang Meraih Kecerdasan, Finansial Berdimensi Spiritual dengan Wakaf ( 2017 ).

Dan yang membedakan tulisan ini dengan tulisan-tulisan sebelumnya adalah terobosan untuk menelaah pasal-pasal UU Wakaf dalam perspektif ekonomi produktif dengan teori yang dikembangkan oleh Qutub Abdul Salam untuk menemukan koherensinya. Pada tulisantulisan sebelumnya lebih fokus pada kasus perkasus atau ada juga yang mendeskripsikan wakaf produktif secara general.

\section{METODE PENELITIAN}

Dalam penelitian ini menggunakan metode analisis isi (content analysis) yaitu analisis yang bersifat pembahasan mendalam terhadap isi suatu informasi tertulis atau tercetak. Dalam hal ini UU No.41 Tahun 2014 tentang Wakaf berusaha untuk dikoherensikan dengan teori ekonomi produktif. Dan teori yang digunakan sebagai pisau analisis adalah teori ekonomi produktif dari Qutub Abdul Salam, dalam dimensi tujuan ekonomi produktif dan faktor-faktor utama yang dibutuhkan. Dengan demikian, penelitian ini sesungguhnya bertujuan untuk menemukan koherensi pasal-pasal dalam UU Wakaf dengan Teori Ekonomi Produktif yang dikembangkan oleh Qutub Abdul Salam.

\section{PEMBAHASAN}

Ketika Menteri Agama, Said Aqil Al Munawwar, mendapatkan usulan dari Sekretariat Negara untuk menyusun draft RUU Wakaf, maka segera mengirim surat kepada Menteri Kehakiman dan Hak Asasi manusia untuk segera melakukan pembaharuan perundang-undangan wakaf. Secara konsisten, dalam surat itu Menteri Agama menyebutkan latar belakang aspek ekonomi produktif dalam wakaf; bahwa pengelolaan wakaf di tanah air memiliki peluang dan prospek pengembangan yang positif, baik dari segi kuantitas maupun pemanfaatannya; perkembangan wakaf pada waktunya akan mengarah menjadi kegiatan investasi dan ekonomi produktif dalam rangka pengentasan kemiskinan dan memajukan kesejahteraan masyarakat, sebagaimana yang telah berjalan di 
beberapa negara muslim seperti Arab Saudi, Mesir, Tunisia, Turki, Bangladesh dan lain-lain.

Dijelaskan pula, tujuan penyusunan RUU tentang Wakaf dari aspek ekonomi, di antaranya; pada huruf (c) meningkatkan kesejahteraan umat Islam dan bangsa Indonesia; pada huruf (g) untuk menampung berkembangnya potensi wakaf yang semakin beragam sejalan dengan perekonomian modern, seperti wakaf tunai, wakaf obligasi, wakaf surat berharga, wakaf atas Hak Kekayaan Intelektual (HAKI) dan lain-lain.

Urgensi wakaf produktif juga disampaikan Menteri Agama ketika mengirim surat permohonan persetujuan prakarsa penyusunan RUU tentang Wakaf kepada Presiden. Dalam surat permohonan itu disertakan latar belakang penyusunan RUU tentang Wakaf dari aspek ekonomi, pada nomor 2 huruf (b) disebutkan; ketentuan mengenai perwakafan yang tercantum dalam perundang-undangan tersebut ( UU No. 5 Tahun 1960; PP No. 28 Tahun 1977; dan Inpres No. 1 Tahun 1991/KHI, penulis) belum dapat dijadikan landasan hukum yang cukup kuat untuk mengatur dan menyelesaikan berbagai persoalan yang menyangkut perwakafan yang dihadapi oleh lembaga keagamaan yang bertindak sebagai nazhir. Sementara itu akhir-akhir ini semakin besar kecenderungan masyarakat untuk melakukan perbuatan hukum berupa wakaf uang, yang belum ada pengaturannya dalam peraturan perundang-undangan, padahal wakaf uang itu dinilai secara ekonomi dapat dipergunakan sebagai sarana pengembangan penghidupan dan kehidupan masyarakat.

Langkah kongkrit menuju pemberdayaan wakaf produktif, tertuang di dalam pasal-pasal UU No. 41 Tahun 2004. Berikut adalah tabel substansi UU Wakaf dalam pemeberdayaan wakaf produktif.

Tabel 1.

Pasal-Pasal dalam UU Wakaf yang Relevan dengan Pemberdayaan Ekonomi

\begin{tabular}{l|l|l}
\hline No & Pasal & \multicolumn{1}{c}{ Substansi } \\
\hline 1 & Pasal 5 & $\begin{array}{l}\text { Wakaf berfungsi mewujudkan potensi dan manfaat } \\
\text { ekonomis harta benda wakaf untuk kepentingan } \\
\text { ibadah dan untuk memajukan kesejahteraan umum. }\end{array}$
\end{tabular}




\begin{tabular}{|c|c|c|}
\hline 2 & $\begin{array}{l}\text { Pasal } 16 \\
\text { ayat }(1)\end{array}$ & $\begin{array}{l}\text { Harta benda wakaf terdiri dari: (a) benda tidak } \\
\text { bergerak; dan (b) benda bergerak. }\end{array}$ \\
\hline & $\begin{array}{l}\text { Pasal } 16 \\
\text { ayat } \\
\text { (3) }\end{array}$ & $\begin{array}{l}\text { Benda tidak bergerak sebagaimana dimaksud pada } \\
\text { ayat (1) huruf a meliputi: (a) hak atas tanah sesuai } \\
\text { dengan ketentuan peraturan perundang-undangan } \\
\text { yang berlaku baik yang sudah maupun belum } \\
\text { terdaftar; (b) bangunan atau bagian bangunan yang } \\
\text { berdiri di atas tanah sebagaimana dimaksud pada } \\
\text { huruf a; a) tanaman dan benda lain yang berkaitan } \\
\text { dengan tanah; b) hak milik atas satuan rumah susun } \\
\text { sesuai dengan ketentuan peraturan perundang- } \\
\text { undangan yang berlaku; c) benda tidak bergerak lain } \\
\text { sesuai dengan ketentuan syari'ah dan peraturan } \\
\text { perundang-undangan yang berlaku. } \\
\text { Benda bergerak sebagaimana dimaksud pada ayat (1) } \\
\text { huruf b adalah harta benda yang tidak bisa habis } \\
\text { karena dikonsumsi, meliputi: (a) uang; (b) logam } \\
\text { mulia; (c) surat berharga; (d) kendaraan; (e) hak atas } \\
\text { kekayaan intelektual; (f) hak sewa; dan (g) benda } \\
\text { bergerak lain sesuai dengan ketentuan syariah dan } \\
\text { peraturan perundang-undangan yang berlaku. }\end{array}$ \\
\hline 3 & Pasal 22 & 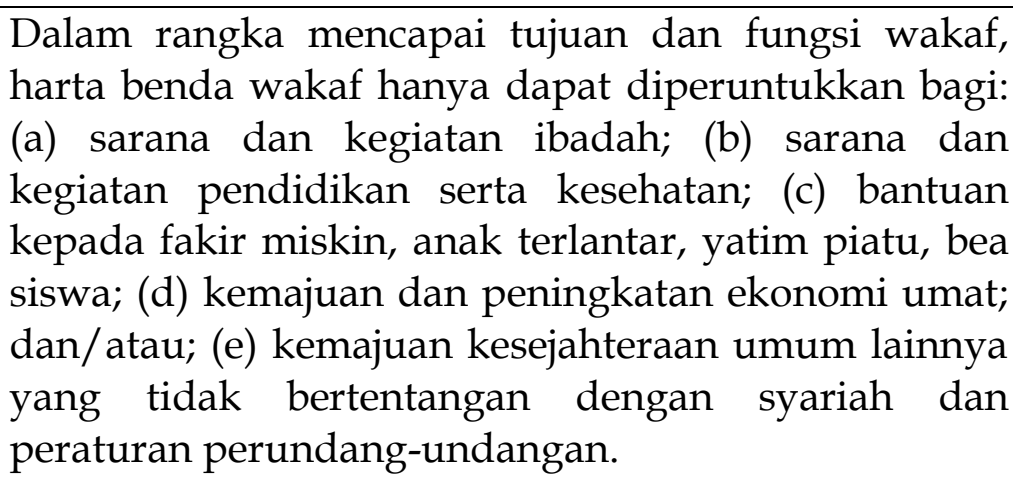 \\
\hline 4 & Pasal 28 & $\begin{array}{l}\text { Wakif dapat mewakafkan benda bergerak berupa } \\
\text { uang melalui lembaga keuangan syariah yang } \\
\text { ditunjuk oleh Menteri. }\end{array}$ \\
\hline
\end{tabular}


$5 \quad$ Pasal $43 \mid$ Pengelolaan dan pengembangan harta benda wakaf ayat (2) sebagaimana dimaksud pada ayat (1) dilakukan secara produktif.

Pasal 43 Dalam hal pengelolaan dan pengembangan harta ayat (3) benda wakaf yang dimaksud pada ayat (1) diperlukan penjamin, maka digunakan lembaga penjamin syariah.

Langkah kongkrit menuju regulasi hukum wakaf demi terciptanya pengelolaan wakaf yang professional dan tertib, dapat dilihat dari pasalpasal UU No. 41 Tahun 2004 tentang Wakaf.

Tabel 2.

Pasal-Pasal UU Wakaf yang Relevan dengan Pengelola Wakaf yang Profesional dan Tertib Administrasi

\begin{tabular}{|c|c|c|}
\hline No & Pasal & Substansi \\
\hline 1 & Pasal 9 & $\begin{array}{l}\text { Nazhir meliputi; (a) perseorangan; (b) organisasi; atau } \\
\text { (c) badan hukum. }\end{array}$ \\
\hline 2 & Pasal 11 & $\begin{array}{l}\text { Nazhir mempunyai tugas; (a) melakukan } \\
\text { pengadministrasian harta benda wakaf; (b) mengelola } \\
\text { dan mengembangkan harta benda wakaf sesuai dengan } \\
\text { tujuan, fungsi dan peruntukannya; (c) mengawasi dan } \\
\text { melindungi harta benda wakaf; (d) melaporkan } \\
\text { pelaksanaan tugas kepada Badan Wakaf Indonesia. }\end{array}$ \\
\hline 3 & Pasal 12 & $\begin{array}{l}\text { Dalam melaksanakan tugas sebagaimana dimaksud } \\
\text { dalam Pasal 11, Nazhir dapat menerima imbalan dari } \\
\text { hasil bersih atas pengelolaan dan pengembangan harta } \\
\text { benda wakaf yang besarnya tidak melebihi } 10 \% \\
\text { (sepuluh persen). }\end{array}$ \\
\hline 4 & sal 13 & $\begin{array}{l}\text { Dalam melaksanakan tugas sebagaimana dimaksud } \\
\text { dalam Pasal 11, Nazhir memperoleh pembinaan dari } \\
\text { Menteri dan Badan Wakaf Indonesia. }\end{array}$ \\
\hline 5 & $\begin{array}{l}\text { sal } 14 \\
\text { at }(1)\end{array}$ & $\begin{array}{l}\text { Dalam rangka pembinaan sebagaimana dimaksud } \\
\text { dalam Pasal 13, Nazhir harus terdaftar pada Menteri } \\
\text { dan Badan Wakaf Indonesia. }\end{array}$ \\
\hline 6 & Pasal 37 & $\begin{array}{l}\text { Menteri dan } \quad \text { Badan } \\
\text { mengadministrasikan pendaftaran harta benda wakaf. }\end{array}$ \\
\hline 7 & Pasal 38 & $\begin{array}{l}\text { Menteri dan Badan Wakaf Indonesia mengumumkan } \\
\text { kepada masyarakat harta benda wakaf yang telah } \\
\text { terdaftar. }\end{array}$ \\
\hline
\end{tabular}




\begin{tabular}{|c|c|c|}
\hline \multirow[t]{3}{*}{8} & $\begin{array}{l}\text { asal } 45 \\
\text { rat }(1)\end{array}$ & $\begin{array}{l}\text { Dalam mengelola dan mengembangkan harta benda } \\
\text { wakaf, Nazhir diberhentikan dan diganti dengan Nazhir } \\
\text { lain apabila Nazhir yang bersangkutan: (a) meninggal } \\
\text { dunia bagi Nazhir perseorangan; (b) bubar atau } \\
\text { dibubarkan sesuai dengan peraturan perundang- } \\
\text { undangan yang berlaku untuk Nazhir organisasi atau } \\
\text { Nazhir badan hukum; (c) atas permintaan sendiri; (d) } \\
\text { tidak melaksanakan tugasnya sebagai Nazhir dan/atau } \\
\text { melanggar ketentuan larangan dalam pengelolaan dan } \\
\text { pengembangan harta benda wakaf sesuai dengan } \\
\text { ketentuan peraturan perundang-undangan yang } \\
\text { berlaku; (e) dijatuhi hukuman pidana oleh pengadilan } \\
\text { yang telah mempunyai kekuatan hukum tetap. }\end{array}$ \\
\hline & $\begin{array}{l}\text { Pasal } 45 \\
\text { ayat }(2)\end{array}$ & $\begin{array}{l}\text { Pemberhentian dan penggantian Nazhir sebagaimana } \\
\text { dimaksud pada ayat (1) dilaksanakan oleh Badan Wakaf } \\
\text { Indonesia. }\end{array}$ \\
\hline & $\begin{array}{l}\text { Pasal } 45 \\
\text { ayat }(3)\end{array}$ & $\begin{array}{l}\text { Pengelolaan dan pengembangan harta benda wakaf } \\
\text { yang dilakukan oleh Nadzir lain karena pemberhentian } \\
\text { dan penggantian Nadzir, dilakukan dengan tetap } \\
\text { memperhatikan peruntukan harta benda wakaf yang } \\
\text { ditetapkan dan tujuan serta fungsi wakaf. }\end{array}$ \\
\hline \multirow[t]{2}{*}{9} & $\begin{array}{l}\text { Pasal } 47 \\
\text { ayat }(1)\end{array}$ & $\begin{array}{l}\text { Dalam rangka memajukan dan mengembangkan } \\
\text { perwakafan nasional, dibentuk Badan Wakaf Indonesia. }\end{array}$ \\
\hline & $\begin{array}{l}\text { Pasal } 47 \\
\text { ayat }(2)\end{array}$ & $\begin{array}{l}\text { Badan Wakaf Indonesia merupakan lembaga } \\
\text { independen dalam melaksanakan tugasnya. }\end{array}$ \\
\hline \multirow[t]{2}{*}{10} & $\begin{array}{l}\text { Pasal } 62 \\
\text { ayat }(1)\end{array}$ & $\begin{array}{l}\text { Penyelesaian sengketa perwakafan ditempuh melalui } \\
\text { musyawarah untuk mencapai mufakat. }\end{array}$ \\
\hline & $\begin{array}{l}\text { Pasal } 62 \\
\text { ayat }(2)\end{array}$ & $\begin{array}{l}\text { Apabila penyelesaian sengketa sebagaimana dimaksud } \\
\text { pada ayat (1) tidak berhasil, sengketa dapat diselesaikan } \\
\text { melalui mediasi, arbritase, atau pengadilan. }\end{array}$ \\
\hline \multirow[t]{2}{*}{11} & $\begin{array}{l}\text { Pasal } 63 \\
\text { ayat }(1)\end{array}$ & $\begin{array}{l}\text { Menteri melakukan pembinaan dan pengawasan } \\
\text { terhadap penyelenggaraan wakaf untuk mewujudkan } \\
\text { tujuan dan fungsi wakaf. }\end{array}$ \\
\hline & $\begin{array}{l}\text { Pasal } 63 \\
\text { ayat }(2)\end{array}$ & $\begin{array}{l}\text { Khusus mengenai pembinaan sebagimana dimaksud } \\
\text { pada ayat (1) Menteri mengikutsertakan Badan Wakaf } \\
\text { Indonesia. }\end{array}$ \\
\hline
\end{tabular}




\begin{tabular}{|c|c|c|}
\hline & $\begin{array}{l}\text { Pasal } 63 \\
\text { ayat (3) }\end{array}$ & $\begin{array}{l}\text { Pembinaan dan pengawasan sebagaimana dimaksud } \\
\text { pada ayat (1) dan ayat (2) dilakukan dengan } \\
\text { memperhatikan saran dan pertimbangan Majelis Ulama } \\
\text { Indonesia. }\end{array}$ \\
\hline 12 & $\begin{array}{l}\text { Pasal } 67 \\
\text { ayat (1) }\end{array}$ & $\begin{array}{l}\text { Setiap orang yang dengan sengaja menjaminkan, } \\
\text { menghibahkan, menjual, mewariskan, mengalihkan } \\
\text { dalam bentuk pengalihan hak lainnya harta benda } \\
\text { wakaf yang telah diwakafkan sebagaimana dimaksud } \\
\text { dalam pasal } 40 \text { atau tanpa izin menukar harta benda } \\
\text { wakaf yang telah diwakafkan sebagaimana dimaksud } \\
\text { dalam Pasal 41, dipidana dengan pidana penjara paling } \\
\text { lama } 5 \text { (lima) tahun dan/atau pidana denda paling } \\
\text { banyak Rp. } 500.000 .000,00 \text { (lima ratus juta rupiah). } \\
\text { Setiap orang yang dengan sengaja menggunakan atau } \\
\text { mengambil fasilitas atas hasil pengelolaan dan } \\
\text { pengembangan harta benda wakaf melebihi jumlah } \\
\text { yang ditentukan sebagaimana dimaksud dalam Pasal } \\
\text { 12, dipidana dengan pidana penjara paling lama } 3 \text { (tiga) } \\
\text { tahun dan/atau pidana denda paling banyak Rp. } \\
\text { 300.000.000,00 (tiga ratus juta rupiah). }\end{array}$ \\
\hline 13 & $\begin{array}{l}\text { Pasal } 68 \\
\text { ayat (1) }\end{array}$ & $\begin{array}{l}\text { Menteri dapat mengenakan sanksi administratif atas } \\
\text { pelanggaran tidak didaftarkannya harta benda wakaf } \\
\text { oleh lembaga keuangan syariah dan PPAIW } \\
\text { sebagaimana dimaksud dalam Pasal } 30 \text { dan Pasal } 32 \text {. } \\
\text { Sanksi administratif sebagaimana dimaksud pada ayat } \\
\text { (1) berupa: (a) perningatan tertulis; (b) penghentian } \\
\text { sementara atau pencabutan izin kegiatan di bidang } \\
\text { wakaf bagi lembaga keuangan syariah; (c) penghentian } \\
\text { sementara dari jabatan atau penghentian dari jabatan } \\
\text { PPAIW. } \\
\text { Ketentuan lebih lanjut mengenai pelaksanaan sanksi } \\
\text { administratif sebagaimana dimaksud pada ayat (1) dan } \\
\text { ayat (2) diatur dengan Peraturan Pemerintah. }\end{array}$ \\
\hline
\end{tabular}

Menurut Qutub Abdul Salam tujuan kegiatan ekonomi produktif adalah meningkatkan kemaslahatan yang bisa diwujudkan dalam 
berbagai bentuk di antaranya: Pemenuhan kebutuhan manusia pada tingkat moderat, menemukan kebutuhan masyarakat dan pemenuhannya, mnyedikan persediaan barang/ jasa di masa depan dan pemenuhan sarana bagi kegiatan sosial dan ibadah kepada Allah. Pada pasal 5 UU Wakaf dijelaskan bahwa wakaf berfungsi mewujudkan potensi dan manfaat ekonomis harta benda wakaf untuk kepentingan ibadah dan untuk memajukan kesejahteraan umum. Pasal lain yang juga relevan dengan tujuan kegiatan ekonomi produktif adalah pasal 22 yang menegaskan dalam rangka mencapai tujuan dan fungsi wakaf, harta benda wakaf hanya dapat diperuntukkan bagi: (a) sarana dan kegiatan ibadah; (b) sarana dan kegiatan pendidikan serta kesehatan; (c) bantuan kepada fakir miskin, anak terlantar, yatim piatu, bea siswa; (d) kemajuan dan peningkatan ekonomi umat; dan/atau; (e) kemajuan kesejahteraan umum lainnya yang tidak bertentangan dengan syariah dan peraturan perundang-undangan.

Dan untuk mempertegas pencapaian tujuan dan fungsi wakaf, maka pada pasal 43 (2) disebutkan mekanisme yang ditempuh adalah dengan pengelolaan dan pengembangan harta wakaf secara produktif. Yang dimaksud Wakaf produktif adalah sebuah skema pengelolaan donasi wakaf dari umat, yaitu dengan memproduktifkan donasi tersebut, hingga mampu menghasilkan surplus yang berkelanjutan. Donasi wakaf dapat berupa benda bergerak, seperti uang dan logam mulia, maupun benda tidak bergerak, seperti tanah dan bangunan. Surplus wakaf produktif inilah yang menjadi sumber dana abadi bagi pembiayaan kebutuhan umat, seperti pembiayaan pendidikan dan pelayanan kesehatan yang berkualitas.

Adapun faktor- faktor untuk produktifitas suatu usaha menurut Qutub Abdul Salam setidaknya memenuhi empat hal: (a). sumber daya alam, (b) pengelola/pekerja, (c) skill dan (d) modal. Sumber daya alam sebagai salah satu faktor dalam pengembangan ekonomi produktif pengelolaan wakaf dalam bentuk tanah, bangunan atau benda tidak bergerak lainnya. Pada pasal 16 (1) disebutkan harta benda wakaf terdiri dari: (a) benda tidak bergerak; dan (b) benda bergerak. Selanjutnya pada ayat (2) b dijelaskan benda tidak bergerak sebagaimana dimaksud pada ayat (1) huruf a meliputi: (a) hak atas tanah sesuai dengan ketentuan peraturan perundang-undangan yang berlaku baik yang sudah maupun belum terdaftar; (b) bangunan atau bagian bangunan yang berdiri di atas tanah sebagaimana dimaksud pada huruf a; a) tanaman dan benda lain yang berkaitan dengan tanah; b) hak milik atas satuan rumah susun sesuai dengan ketentuan peraturan perundang-undangan yang berlaku; c) benda tidak bergerak lain sesuai dengan ketentuan syari'ah dan peraturan perundang-undangan yang berlaku. 
Faktor produktifitas dalam bentuk pengelola atau pekerja yang mengurus dan menjalankan harta benda wakaf adalah nazir. Ketentuan nazir tercantum di dalam pasal 9 yang meliputi; (a) perseorangan; (b) organisasi; atau (c) badan hukum. Adapun tugas nazhir disebutkan dalam pasal 11 yaitu; (a) melakukan pengadministrasian harta benda wakaf; (b) mengelola dan mengembangkan harta benda wakaf sesuai dengan tujuan, fungsi dan peruntukannya; (c) mengawasi dan melindungi harta benda wakaf; (d) melaporkan pelaksanaan tugas kepada Badan Wakaf Indonesia. Untuk menunjang kinerja nazir wakaf maka nazir berhak mendapatkan imbalan. Pasal 12 menegaskan dalam melaksanakan tugas sebagaimana dimaksud dalam Pasal 11, Nazhir dapat menerima imbalan dari hasil bersih atas pengelolaan dan pengembangan harta benda wakaf yang besarnya tidak melebihi 10\% (sepuluh persen).

Skill merupakan faktor produktifitas yang sangat penting dalam mengelola harta benda wakaf. Nazir selaku pengelola wakaf akan mendapatkan pembinaan dari Menteri Agama dan Badan Wakaf Indonesia (BWI). Pasal 13 UU Wakaf menyebutkan, dalam melaksanakan tugas sebagaimana dimaksud dalam Pasal 11, Nazhir memperoleh pembinaan dari Menteri dan Badan Wakaf Indonesia. Pada pasal 63 disebutkan lebih lanjut tentang pembinaan yang dilakukan oleh menteri, yaitu Menteri melakukan pembinaan dan pengawasan terhadap penyelenggaraan wakaf untuk mewujudkan tujuan dan fungsi wakaf. Khusus mengenai pembinaan sebagimana dimaksud pada ayat (1) Menteri mengikutsertakan Badan Wakaf Indonesia. Pembinaan dan pengawasan sebagaimana dimaksud pada ayat (1) dan ayat (2) dilakukan dengan memperhatikan saran dan pertimbangan Majelis Ulama Indonesia.

Faktor modal dalam konteks pengelolaan harta wakaf adalah obyek wakaf. Dalam UU Wakaf obyek wakaf meliputi benda bergerak dan tidak bergerak. Selama ini obyek wakaf lebih di dominasi benda-benda tidak bergerak seperti, tanah dan bangunan. Namun dengan keluarnya UU Wakaf No 41 Tahun 2014 maka benda tidak bergerak menjadi tambahan modal penting dalam pengembangan wakaf produktif. Di dalam pasal 16 (3) disebutkan benda bergerak sebagaimana dimaksud pada ayat (1) huruf $b$ adalah harta benda yang tidak bisa habis karena dikonsumsi, meliputi: (a) uang; (b) logam mulia; (c) surat berharga; (d) kendaraan; (e) hak atas kekayaan intelektual; (f) hak sewa; dan (g) benda bergerak lain sesuai dengan ketentuan syariah dan peraturan perundang-undangan yang berlaku.

\section{KESIMPULAN}

Dari hasil pengumpulan data dan analisis maka dapat disimpulkan bahwa UU Wakaf kohern dengan teori ekonomi produktif. Tujuan 
kegiatan ekonomi produktif adalah meningkatkan kemaslahatan yang bisa diwujudkan dalam berbagai bentuk di antaranya: Pemenuhan kebutuhan manusia pada tingkat moderat, menemukan kebutuhan masyarakat dan pemenuhannya, mnyedikan persediaan barang/ jasa di masa depan dan pemenuhan sarana bagi kegiatan sosial dan ibadah kepada Allah. Pada pasal 5 UU Wakaf dijelaskan bahwa wakaf berfungsi mewujudkan potensi dan manfaat ekonomis harta benda wakaf untuk kepentingan ibadah dan untuk memajukan kesejahteraan umum. Pasal lain yang juga relevan dengan tujuan kegiatan ekonomi produktif adalah pasal 22 yang menegaskan dalam rangka mencapai tujuan dan fungsi wakaf, harta benda wakaf hanya dapat diperuntukkan bagi: sarana dan kegiatan ibadah, sarana dan kegiatan pendidikan serta kesehatan, bantuan kepada fakir miskin, anak terlantar, yatim piatu, bea siswa, kemajuan dan peningkatan ekonomi umat; dan/atau kemajuan kesejahteraan umum lainnya yang tidak bertentangan dengan syariah dan peraturan perundang-undangan.

Faktor- faktor produktifitas suatu usaha mencakup empat hal: sumber daya alam, pengelola/pekerja, skill dan modal. Faktor sumber daya alam sebagai salah satu faktor dalam pengembangan ekonomi produktif kohern dengan UU Wakaf yaitu obyek wakaf dalam bentuk tanah, bangunan atau benda tidak bergerak lainnya. Faktor produktifitas dalam bentuk pengelola atau pekerja yang mengurus dan menjalankan harta benda wakaf adalah nazir yang meliputi; perseorangan, organisasi, atau badan hukum. Adapun tugas nazhir adalah; melakukan pengadministrasian harta benda wakaf, mengelola dan mengembangkan harta benda wakaf sesuai dengan tujuan, fungsi dan peruntukannya, mengawasi dan melindungi harta benda wakaf dan melaporkan pelaksanaan tugas kepada Badan Wakaf Indonesia Skill merupakan faktor produktifitas yang sangat penting dalam mengelola harta benda wakaf. Nazir selaku pengelola wakaf akan mendapatkan pembinaan dari Menteri Agama dan Badan Wakaf Indonesia (BWI) baik dari aspek skill maupun managerial. Faktor modal dalam konteks pengelolaan harta wakaf adalah obyek wakaf. Dalam UU Wakaf obyek wakaf meliputi benda bergerak dan tidak bergerak. Selama ini obyek wakaf lebih di dominasi benda-benda tidak bergerak seperti, tanah dan bangunan. Namun dengan keluarnya UU Wakaf No 41 Tahun 2014 maka benda tidak bergerak menjadi tambahan modal penting dalam pengembangan wakaf produktif. Harta benda bergerak yang tidak bisa habis karena dikonsumsi meliputi: uang, logam mulia, surat berharga, kendaraan,hak atas kekayaan intelektual, hak sewa dan benda bergerak lain sesuai dengan ketentuan syariah dan peraturan perundang-undangan yang berlaku. 


\section{DAFTAR PUSTAKA}

Ali Sabri, F. (2013). Wakaf Uang sebagai Alternatif dalam Mensejahterakan Ummat, Jurnal Al Ihkam,. Vol.8 , No 41.

Azhary, Tahir, M., (2004), Kumpulan Hasil Seminar Perwakafan, Jakarta: Direktorat Pengembangan Zakat dan Wakaf Depag RI.

Candra, Hari. (2017). Peran Lembaga Pendidikan Wakaf dalam Membentuk Karakter Bertoleransi, Jurnal Ziswaf, Vol.4, No.2.

Djunaidi, Achmad, dan Thobieb Al-Asyhar, (2007), Menuju Era Wakaf Produktif, Jakarta: Mumtaz Publishing.

Furqon,Ahmad. (2012). Wakaf Sebagai Solusi Permasalahan-permasalahan Dunia Pendidikan Di Indonesia, Jurnal Hukum Islam (JHI), Volume 10, Nomor 1.

Hadi, Choirul, Peluang Wakaf Produktif untuk Pembiayaan Pendidikan Islam, Turats, Vol.5, Nomor 1.

Hanifiyyah, Spiritualitas Islam dalam Kewirausahaan, Jurnal Peradaban Islam, Vol 12, No1, Mei 2016

Hasanah, Uswatun. (2008). Wakaf dalam Peraturan Perundang-undangan di Indonesia, Jurnal Wakaf dan Ekonomi Islam Al-Awqaf BWI, Volume 1 Nomor 01.

Hilmi, Hasbullah. (2012). Dinamika Pengelolaan Uang Wakaf (Studi tentang Perilaku Pengelolaan Wakaf Uang Pasca Pemberlakuan UU No. 41 Tahun 2004), Disertasi Pasca Sarjana IAIN Walisongo Semarang.

Khusaeri. (2015). Wakaf Produktif, Jurnal Al A'raf, Vol XII, No.1.

Naim, Abdul Haris. (2017). Pengembangan Obyek Wakaf dalam Fiqh Islam dan Hukum Positif di Indonesia, Jurnal Ziswaf,Vol 4, No.2.

Najib, Tuti A. Dan Ridwan al-Makassary (ed.), (2006), Wakaf, Tuhan dan Agenda Kemanusiaan, Jakarta: Centre for the Study and Culture (CSRC) UIN Jakarta.

Praja, Juhaya S., (1997), Perwakafan di Indonesia: Sejarah, Pemikiran, Hukum dan Perkembangannya, Bandung: Yayasan Piara.

Suminto, Aqib, (1985), Politik Islam Hindia Belanda, Jakarta: LP3ES.

Zahrotul Jannah, Diyah Ayu. (2017). Meraih Kecerdasan, Finansial Berdimensi Spiritual dengan Wakaf, Jurnal Ziswaf, Vol 4, Nomor 2. 